\title{
Five year mortality and direct costs of care for people with diabetic foot complications are comparable to cancer
}

David G. Armstrong ${ }^{*}$, Mark A. Swerdlow, Alexandria A. Armstrong, Michael S. Conte, William V. Padula and Sicco A. Bus

\begin{abstract}
Background: In 2007, we reported a summary of data comparing diabetic foot complications to cancer. The purpose of this brief report was to refresh this with the best available data as they currently exist. Since that time, more reports have emerged both on cancer mortality and mortality associated with diabetic foot ulcer (DFU), Charcot arthropathy, and diabetes-associated lower extremity amputation.

Methods: We collected data reporting 5-year mortality from studies published following 2007 and calculated a pooled mean. We evaluated data from DFU, Charcot arthropathy and lower extremity amputation. We dichotomized high and low amputation as proximal and distal to the ankle, respectively. This was compared with cancer mortality as reported by the American Cancer Society and the National Cancer Institute.

Results: Five year mortality for Charcot, DFU, minor and major amputations were 29.0, 30.5, 46.2 and 56.6\%, respectively. This is compared to $9.0 \%$ for breast cancer and $80.0 \%$ for lung cancer. 5 year pooled mortality for all reported cancer was $31.0 \%$.

Direct costs of care for diabetes in general was $\$ 237$ billion in 2017. This is compared to $\$ 80$ billion for cancer in 2015. As up to one-third of the direct costs of care for diabetes may be attributed to the lower extremity, these are also readily comparable.

Conclusion: Diabetic lower extremity complications remain enormously burdensome. Most notably, DFU and LEA appear to be more than just a marker of poor health. They are independent risk factors associated with premature death. While advances continue to improve outcomes of care for people with DFU and amputation, efforts should be directed at primary prevention as well as those for patients in diabetic foot ulcer remission to maximize ulcer-free, hospital-free and activity-rich days.
\end{abstract}

Up to one-third of the half billion people with diabetes worldwide will develop a diabetic foot ulcer (DFU) over the course of their lifetime. Over half of DFUs will develop an infection. Of these, $17 \%$ will require an amputation [1-4]. Remarkably, people with diabetes fear amputation worse than death [5]. For patients who do

\footnotetext{
*Correspondence: armstrong@usa.net

Southwestern Academic Limb Salvage Alliance (SALSA), Department of Surgery, Keck School of Medicine of University of Southern California, Los Angeles, USA
}

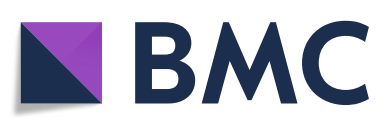

(c) The Author(s). 2020 Open Access This article is licensed under a Creative Commons Attribution 4.0 International License, which permits use, sharing, adaptation, distribution and reproduction in any medium or format, as long as you give appropriate credit to the original author(s) and the source, provide a link to the Creative Commons licence, and indicate if changes were made. The images or other third party material in this article are included in the article's Creative Commons licence, unless indicated otherwise in a credit line to the material. If material is not included in the article's Creative Commons licence and your intended use is not permitted by statutory regulation or exceeds the permitted use, you will need to obtain permission directly from the copyright holder. To view a copy of this licence, visit http://creativecommons.org/licenses/by/4.0/. The Creative Commons Public Domain Dedication waiver (http://creativecommons.org/publicdomain/zero/1.0/) applies to the data made available in this article, unless otherwise stated in a credit line to the data.

not receive amputation and are able to heal their ulcer, $40 \%$ will develop a recurrence within 1 year, $65 \%$ within 5 years, and greater than $90 \%$ within 10 years $[1,6]$. The greatest risk factor for a DFU is a previously healed DFU. These silent, sinister complications are now a leading cause of disability worldwide [7, 8]. Despite this high prevalence and morbidity, federal funding for studies related to DFUs remains at a 600-plus-fold disadvantage compared to other diabetes research in terms of public 
health impact. The disparity is even greater when compared to cancer research [9].

In 2007, we reported a summary of data comparing diabetic foot complications to cancer [10]. We thought that it might be appropriate to refresh this with the best available data as they currently exist. Since that time, more reports have emerged both on cancer mortality [11] and mortality associated with DFU, [12-14] Charcot arthropathy, [15-17] and diabetes-associated lower extremity amputation [18-27]. We collected data containing 5 -year mortality from studies published after the previous publication in 2007 and calculated a pooled mean.

The mortality rate for people who undergo lower extremity amputation due to a DFU remains alarming: more than half of people with a major amputation will be dead in 5 years [21-25]. (Fig. 1). 5 year mortality for Charcot, DFU, minor and major amputations were 29.0, 30.5, 46.2 and 56.6\%, respectively. This is even higher in people with concomitant chronic kidney disease and other comorbidities [25].

Certainly, an important component of mortality in people with lower extremity complications of diabetes can be attributed to the severity of comorbidities with these patients often present - namely cardiovascular and renal disease worsened by reduced mobility [7]. This most certainly further reduces the attribution of cause away from lower extremity morbidity and toward a more familiar cardiovascular etiology. Indeed, people with a history of DFU have a life expectancy fully 5 years lower than age and disease-matched controls. The primary cause of death in these patients was listed as ischemic heart disease [30]. It is important to note, however, that,
DFU and LEA appear to be more than just a marker of poor health. They are independent risk factors associated with premature death [31].

It is for these reasons that we have argued for a change in the syntax surrounding DFUs and other associated complications. Considering patients with healed DFUs as patients "in remission" rather than formally "healed" makes it easier for the patient, other clinicians, and policymakers to understand the possibility, or as the data suggest, probability, of a recurrence and to better communicate overall risk $[1,32]$. It also indicates the need for regular follow-up and helps to prepare the patient for a lifetime of preventative management and mobility training [32]. With this mindset, patients can be properly educated about the dangers of diabetic foot disease and work towards maximizing ulcer-free, hospital-free, and activity-rich days, the same way a cancer survivor works to maximize cancer-free days $[33,34]$.

\section{The economic cost of DFUs}

DFUs place a great economic burden on society, both to our healthcare system and due to lost productivity. In 2017 , diabetes directly cost $\$ 237$ billion in the USA, a $26 \%$ increase from 2012. On the order of one-third of these direct costs were attributable to care for diabetic foot disease $[1,35,36]$. In remarkable contrast, the 2015 direct costs for cancer in the USA were $\$ 80.2$ billion nearly equal to the attributable cost of diabetic foot disease [37]. As the number of people with diabetes is expected to rise over the coming decades we do not expect this cost or the rate at which it spirals out of
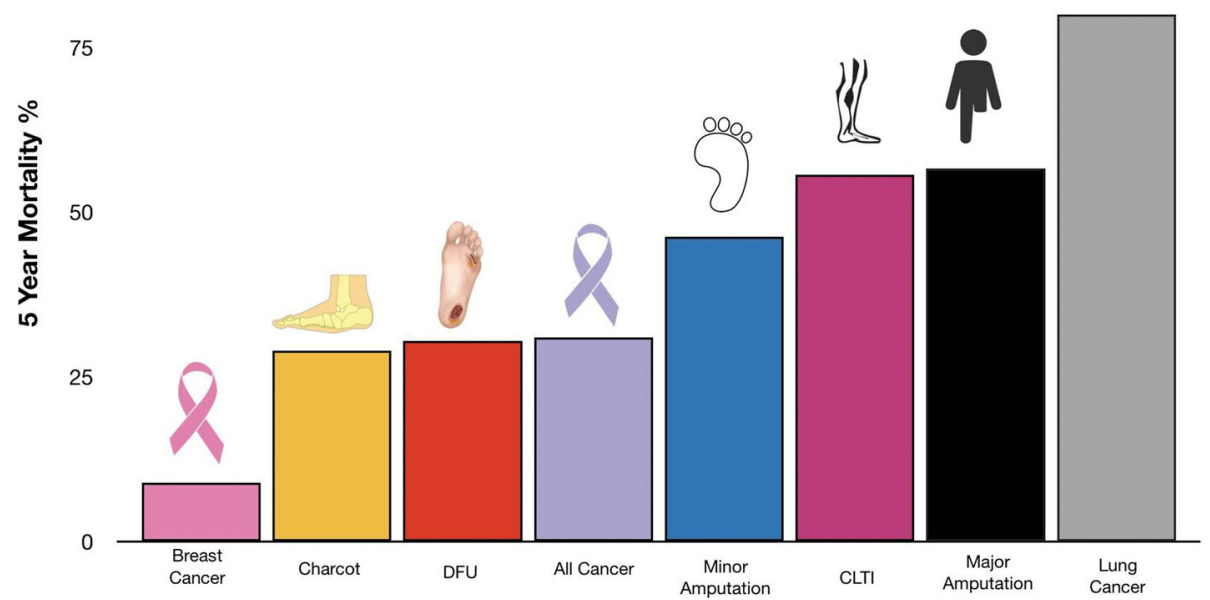

Fig. 1 Five Year Mortality of Diabetic Foot Complications and Cancer. Diabetic foot complications compared to cancer. DFU = diabetic foot ulcers $[11]=30.5 \%$. Charcot $=$ Charcot neuroarthropathy of the foot [14]. All Cancer $=$ pooled 5 year survival of all cancers [11]. CLTI $=$ chronic limb threatening ischemia [28, 29]. Major Amputation = above foot amputation [20-22, 26, 27]. Minor Amputation = foot level amputation [17, 27] 
control to slow down unless more serious measures are spent on preventive education and care. The U.S. National Cancer Institute's budget is currently \$6.4 billion to explore technological innovations in treatments and cures for cancer, and there should be a proportional response for diabetic foot disease [38]. Although patient education can play an important first step in the management of diabetic foot disease, new technologies are emerging which may help to reduce healing times, ulcer severity at clinical presentation, and overall costs.

Additionally, the emergence of remote patient monitoring technologies can allow us to predict and detect ulcers as or even before they form. Patients using a smart insole system, pressure-monitoring insoles transmitting real-time feedback to a smartwatch to cue offloading of sustained plantar pressure, in addition to the regular standard-of-care have been shown to have substantially lower rates of ulcer occurrence and approximately $\$ 15,000$ less cost of care when ulcers do form, over a period of 18 months [39, 40]. In another study, a smart temperature-monitoring bathmat was able to detect DFUs 5 weeks before clinical presentation [41]. Further, in-clinic hyperspectral imaging devices have shown great promise in detecting wound formation weeks in advance and providing clinicians with useful information into the blood flow to current wounds, aiding in treatment decision-making [42]. Since the difference in cost between an early-stage DFU and a more severe DFU is at least an order of magnitude lower in almost every economy measured, [43] technologies that can help identify DFUs early or before they even form will be useful tools for patients, clinicians and health systems [44]. As these devices progress to be used in the home, along with other easy-to-use devices, we are hopeful that these technologies will help to alleviate the incidence of and costs associated with DFUs.

Altogether, these breakthroughs in technology and best-practice adherence offer providers and patients with economically dominant strategies to manage diabetic foot complications. Such strives are critical since the anticipated $\$ 80$ billion currently being spent on diabetic foot disease is not sustainable. For merely pennies on the dollar, investment in prevention of this concerning complication represents a more economical practice and is better for the patient. Furthermore, monetary savings gained from the transition between treatment and prevention can be used to perpetuate further investments to address mitigating root causes of diabetes complications so that future patients suffer less.

In summary, complications associated with diabetic foot disease remain common, complex and costly. The economic impact of diabetic foot disease is comparable to cancer in every single way, but supportive technologies to predict and prevent onset offers healthcare potential savings in the short-run. Most importantly, focusing on early-stage preventative therapies and long-term supportive therapies for people in diabetic foot remission may yield both a greater lifespan and healthspan for the people we serve.

\section{Acknowledgements \\ N/A \\ Authors' information (optional) \\ N/A}

\section{Authors' contributions}

All authors wrote part of the manuscript and edited the manuscript. All authors were involved in data collection and analysis for generated figure. All authors read and approved the final manuscript.

\section{Funding}

N/A

Availability of data and materials

Please contact author for data requests.

Ethics approval and consent to participate

N/A

Consent for publication

N/A

Competing interests

The authors declare that they have no competing interests.

Received: 15 January 2020 Accepted: 17 March 2020

Published online: 24 March 2020

\section{References}

1. Armstrong DG, Boulton AJM, Bus SA. Diabetic foot ulcers and their recurrence. N Engl J Med. 2017:376(24):2367-75.

2. Infection guideline - IWGDF Guidelines. IWGDF Guidelines. https:// iwgdfguidelines.org/infection-guideline/. Published May 25, 2019. Accessed December 22, 2019

3. Prompers L, Huijberts M, Apelqvist J, et al. High prevalence of ischaemia, infection and serious comorbidity in patients with diabetic foot disease in Europe. Baseline results from the Eurodiale study. Diabetologia. 2007:50:18-25.

4. IDF Diabetes Atlas 9th edition 2019. https://diabetesatlas.org/en/. Accessed December 6, 2019.

5. Wukich DK, Raspovic KM, Suder NC. Patients with diabetic foot disease fear major lower-extremity amputation more than death. Foot Ankle Spec. 2018; 11(1):17-21

6. Huang Z-H, Li S-Q, Kou Y, Huang L, Yu T, Hu A. Risk factors for the recurrence of diabetic foot ulcers among diabetic patients: a meta-analysis. Int Wound J. 2019. https://doi.org/10.1111/iwj.13200.

7. Lazzarini PA, Pacella RE, Armstrong DG, van Netten JJ. Diabetes-related lower-extremity complications are a leading cause of the global burden of disability. Diabet Med. 2018. https://doi.org/10.1111/dme.13680.

8. Zhang Y, Lazzarini PA, McPhail SM, van Netten JJ, Armstrong DG, Pacella RE. Global Disability Burdens of Diabetes-Related Lower-Extremity Complications in 1990 and 2016. Diabetes Care. 2020. https://doi.org/10. 2337/dc19-1614.

9. Armstrong DG, Kanda VA, Lavery LA, Marston W, Mills JL Sr, Boulton AJM. Mind the gap: disparity between research funding and costs of care for diabetic foot ulcers. Diabetes Care. 2013;36(7):1815-7.

10. Armstrong DG, Wrobel J, Robbins JM. Guest editorial: are diabetes-related wounds and amputations worse than cancer? Int Wound J. 2007:4(4):286-7.

11. Cancer Facts \& Figures 2019. https://www.cancer.org/content/dam/cancerorg/research/cancer-facts-and-statistics/annual-cancer-facts-and-figures/201 9/cancer-facts-and-figures-2019.pdf. 
12. Jeyaraman K, Berhane T, Hamilton M, Chandra AP, Falhammar H. Mortality in patients with diabetic foot ulcer: a retrospective study of 513 cases from a single Centre in the Northern Territory of Australia. BMC Endocr Disord. 2019;19(1):1.

13. Amadou C, Carlier A, Amouyal C, et al. Five-year mortality in patients with diabetic foot ulcer during 2009-2010 was lower than expected. Diabetes Metab. 2019. https://doi.org/10.1016/j.diabet.2019.04.010.

14. Winkley K, Sallis H, Kariyawasam D, et al. Five-year follow-up of a cohort of people with their first diabetic foot ulcer: the persistent effect of depression on mortality. Diabetologia. 2012;55(2):303-10.

15. Sohn M-W, Lee TA, Stuck RM, Frykberg RG, Budiman-Mak E. Mortality risk of Charcot arthropathy compared with that of diabetic foot ulcer and diabetes alone. Diabetes Care. 2009:32(5):816-21.

16. Gazis A, Pound N, Macfarlane R, Treece K, Game F, Jeffcoate W. Mortality in patients with diabetic neuropathic osteoarthropathy (Charcot foot). Diabet Med. 2004;21(11):1243-6.

17. Armstrong DG, Peters EJG. Charcot's arthropathy of the foot. J Am Podiatr Med Assoc. 2002;92(7):390-4.

18. Wilbek TE, Jansen RB. Jørgensen B, Svendsen OL. The diabetic foot in a multidisciplinary team setting. Number of amputations below ankle level and mortality. Exp Clin Endocrinol Diabetes. 2016;124(9):535-40.

19. Uzzaman MM, Jukaku S, Kambal A, Hussain ST. Assessing the long-term outcomes of minor lower limb amputations: a 5-year study. Angiology. 2011;62:365-71.

20. McEwen LN, Ylitalo KR, Munson M, Herman WH, Wrobel JS. Foot complications and mortality: results from translating research into action for diabetes (TRIAD). J Am Podiatr Med Assoc. 2016;106(1):7-14.

21. Huang $Y-Y$, Lin C-W, Yang H-M, Hung S-Y, Chen I-W. Survival and associated risk factors in patients with diabetes and amputations caused by infectious foot gangrene. J Foot Ankle Res. 2018;11:1.

22. Morbach S, Furchert $H$, Gröblinghoff $U$, et al. Long-term prognosis of diabetic foot patients and their limbs: amputation and death over the course of a decade. Diabetes Care. 2012;35(10):2021-7.

23. Moulik PK, Mtonga R, Gill GV. Amputation and mortality in new-onset diabetic foot ulcers stratified by etiology. Diabetes Care. 2003;26:491-4.

24. Izumi Y, Satterfield K, Lee S, Harkless LB, Lavery LA. Mortality of first-time amputees in diabetics: a 10-year observation. Diabetes Res Clin Pract. 2009; 83(1):126-31.

25. Lavery LA, Hunt NA, Ndip A, Lavery DC, Van Houtum W, Boulton AJM. Impact of chronic kidney disease on survival after amputation in individuals with diabetes. Diabetes Care. 2010;33(11):2365-9.

26. Kelly PJ, Clarke PM, Hayes AJ, et al. Predicting mortality in people with type 2 diabetes mellitus after major complications: a study using Swedish National Diabetes Register data. Diabet Med. 2014;31(8):954-62.

27. Kim YK, Lee HS, Ryu JJ, In Lee H, Seo SG. Sarcopenia increases the risk for mortality in patients who undergo amputation for diabetic foot. J Foot Ankle Res. 2018;11(1):32.

28. Duff $S$, Mafilios MS, Bhounsule P, Hasegawa JT. The burden of critical limb ischemia: a review of recent literature. Vasc Health Risk Manag. 2019;15:187-208.

29. Spreen Ml, Gremmels H, Teraa M, et al. Diabetes is associated with decreased limb survival in patients with critical limb ischemia: pooled data from two randomized controlled trials. Diabetes Care. 2016;39(11):2058-64.

30. Chammas NK, Hill RLR, Edmonds ME. Increased mortality in diabetic foot ulcer patients: the significance of ulcer type. J Diabetes Res. 2016;2016: 2879809.

31. Martins-Mendes D, Monteiro-Soares M, Boyko EJ, et al. The independent contribution of diabetic foot ulcer on lower extremity amputation and mortality risk. J Diabetes Complications. 2014;28(5):632-8.

32. Armstrong DG, Mills JL. Toward a change in syntax in diabetic foot care: prevention equals remission. J Am Podiatr Med Assoc. 2013;103(2):161-2.

33. Khan T, Armstrong DG. Ulcer-free, hospital-free and activity-rich days: three key metrics for the diabetic foot in remission. J Wound Care. 2018;27(Sup4):S3-4.

34. AJM B, Armstrong DG, Kirsner RS, et al. Diagnosis and Management of Diabetic Foot Complications. Arlington (VA): American Diabetes Association; 2019.

35. The Cost of Diabetes | ADA. https://www.diabetes.org/resources/statistics/ cost-diabetes. Accessed December 22, 2019.

36. Driver VR, Fabbi M, Lavery LA, Gibbons G. The costs of diabetic foot: the economic case for the limb salvage team. J Vasc Surg. 2010;52(3 Suppl): $175-22 S$.
37. Economic Impact of Cancer. https://www.cancer.org/cancer/cancer-basics/ economic-impact-of-cancer.html. Accessed December 22, 2019.

38. $\mathrm{NCl}$ Budget and Appropriations. National Cancer Institute. https://www. cancer.gov/about-nci/budget. Published 2015. Accessed January 8, 2020

39. Najafi B, B Chalifoux C, Everett JB, Razjouyan J, A Brooks E, G Armstrong D. Cost effectiveness of smart insoles in preventing ulcer recurrence for people in diabetic foot remission. Wound Care Manage. 2018;1(1). https://doi.org/ 10.15761/WCM.1000102.

40. Raviglione A, Reif R, Macagno M, Vigano D, Schram J, Armstrong D. Realtime smart textile-based system to monitor pressure offloading of diabetic foot ulcers. J Diabetes Sci Technol. 2017:11(5):894-8.

41. Frykberg RG, Gordon IL, Reyzelman AM, et al. Feasibility and efficacy of a smart mat Technology to predict development of diabetic plantar ulcers. Diabetes Care. 2017;40(7):973-80

42. Weinkauf C, Mazhar A, Vaishnav K, Hamadani AA, Cuccia DJ, Armstrong DG. Near-instant noninvasive optical imaging of tissue perfusion for vascular assessment. J Vasc Surg. 2019;69(2):555-62.

43. Cavanagh P, Attinger C, Abbas Z, Bal A, Rojas N, Xu Z-R. Cost of treating diabetic foot ulcers in five different countries. Diabetes Metab Res Rev. 2012;28(Suppl 1):107-11.

44. Armstrong DG. Subscription prescription: remote patient monitoring using smart shoes, socks and insoles. J Wound Care. 2019;28(Sup9):S3.

\section{Publisher's Note}

Springer Nature remains neutral with regard to jurisdictional claims in published maps and institutional affiliations.

\section{Ready to submit your research? Choose BMC and benefit from:}

- fast, convenient online submission

- thorough peer review by experienced researchers in your field

- rapid publication on acceptance

- support for research data, including large and complex data types

- gold Open Access which fosters wider collaboration and increased citations

- maximum visibility for your research: over $100 \mathrm{M}$ website views per year

At BMC, research is always in progress.

Learn more biomedcentral.com/submissions 